\title{
Forage mass and nutritional value of elephant grass intercropped with forage legumes ${ }^{1}$
}

\author{
Daiane Cristine Seibt *iD, Clair Jorge Olivo², Vinicius Alessio', Caroline Paim Sauter ${ }^{2}$, \\ Vinicius Felipe Bratz ${ }^{2}$, Priscila Flôres Aguirre ${ }^{2}$
}

$10.1590 / 0034-737 X 202168050008$

\begin{abstract}
Forage-legume systems are a sustainable and competitive alternative for improving pasture yield and quality because of the symbiotic nitrogen fixation capacity and high nutritional value of legumes. This study aimed to evaluate the forage mass, nutritional value, and nutrient export rate in three forage systems (FS): FS1, with elephant grass (Pennisetum purpureum) (EG), annual ryegrass (Lolium multiflorum) (AR), and spontaneous growth species (SGS); FS2, with EG + $\mathrm{AR}+\mathrm{SGS}+$ arrowleaf clover (Trifolum vesiculosum); and FS3, with EG + AR + SGS + forage peanut (Arachis pintoi). The experiment was arranged in a completely randomized design, with three replicates, and repeated measures over time. Results of pre-grazing forage mass were 3.5, 3.8, and $3.9 \mathrm{t} / \mathrm{ha}$, and crude protein export were 1.4, 2.1, and $2.3 \mathrm{t} / \mathrm{ha}$, for the treatments FS1, FS2 and FS3, respectively. Highest crude protein, in situ dry matter digestibility and total digestible nutrients, and lowest neutral detergent fiber were found in the intercropping system with forage peanut, especially in winter. Nutritional values were also better in legume-systems than the non-legume system.
\end{abstract}

Keywords: Arachis pintoi; Crude protein; Digestibility; Neutral detergent fiber; Trifolum vesiculosum.

\section{INTRODUCTION}

Elephant grass (Pennisetum purpureum Schum.) is a perennial grass native to Africa. The high yield, palatability, and persistence of this grass make it an important alternative forage to native species for livestock in different tropical and subtropical regions (Oliveira et al., 2011). Forage grasses are mainly used in the conventional strategy of production as monocrops. This strategy simplify the use of pastures, but forage production is concentrated in certain periods of the year and fertilizer costs are high (Olivo et al., 2014). In addition, the low quality of most tropical grasses is a limiting factor for livestock production in the tropics (Kozloski et al., 2003).

A strategy for making forage systems more sustainable is intercropping with legume species, which allows better supply of forage over time, reduces costs with fertilization, and minimizes environmental impacts, mainly due to a lower nitrogen fertilizer input (Lüscher et al.,
2014). The presence of legume species in the pasture composition contributes to increasing nutrient amount and improving animal performance, as well as being a low cost alternative to monocrop systems (Barcellos et al., 2008). Despite their potential benefits, the slower establishment of legumes in relation to grasses, indicating their low persistence, is among the main reasons for their little use in forage systems (Abdul-Baki et al., 2002). On that account, the cultivation of elephant grass with a wider between-row distance and its clump growth habit may favor the development of legume species if they are established between rows (Olivo et al., 2017). Among these species, forage peanut (Arachis pintoi) and those of the genus Trifolium stand out due to their high nutritional value (Barcellos et al., 2008; Tambara et al., 2017) and, to improving quality and forage supply over the year when intercropped with other species (Azevedo Junior et al., 2012; Olivo et al., 2017).

\footnotetext{
Submitted on March 08th, 2019 and accepted on June 11 th, 2021.

${ }^{1}$ This work is part of the first author's Master Dissertation.

${ }^{2}$ Universidade Federal de Santa Maria, Departamento de Zootecnia, Santa Maria, Rio Grande do Sul, Brazil. daianecseibt@gmail.com; clairolivo@yahoo.com.br; viniciusalessio@ hotmail.com; carolsauter26@gmail.com; viniciusbratz@hotmail.com; priscilafloresaguirre@yahoo.com.br

*Corresponding author: daianecseibt@gmail.com
} 
The main hypothesis of this work is that the nutritional value of elephant grass pastures varies according to the production system used. Therefore, the aim of this study was to evaluate forage mass, nutritional value, and nutrient export in forage systems of elephant grass intercropped with forage peanut or arrowleaf clover (Trifolum vesiculosum) under grazing by dairy cows.

\section{MATERIAL AND METHODS}

This project was approved by the Ethics and Biosafety Committee of UFSM by the opinion 113/2011 and protocol no 23081016073/2011.

The experiment was conducted in an area of the Department of Animal Science of the Federal University of Santa Maria (UFSM), located in the Central Depression region of the State of Rio Grande do Sul, between May 2013 and April 2014. The soil is classified as a dystrophic arenic Red Argisol, of the São Pedro mapping unit (Streck et al., 2008), with the following characteristics: $\mathrm{pH}$ in $\mathrm{H}_{2} \mathrm{O}$ $=5.8 ; \mathrm{SMP}$ index $=6.1 ;$ clay $=23 \% ; \mathrm{P}=16.6 \mathrm{mg} \mathrm{dm}^{-3} ; \mathrm{K}=96$ $\mathrm{mg} \mathrm{dm}{ }^{-3} ; \mathrm{OM}=3.5 \% ; \mathrm{Al}=0.0 \mathrm{cmolc} \mathrm{dm}^{-3} ; \mathrm{Ca}=7.1 \mathrm{cmol}_{\mathrm{c}}$ $\mathrm{dm}^{-3} ; \mathrm{Mg}=3.1 \mathrm{cmol}_{\mathrm{c}} \mathrm{dm}^{-3} ;$ base saturation $=70.9 \%$, and $\mathrm{Al}$ saturation $=0 \%$.

According to Köppen, the climate is Cfa, subtropical humid (Kuinchtner \& Buriol, 2016). The climate normals for air temperature and rainfall are $19.2^{\circ} \mathrm{C}$ and $141 \mathrm{~mm} /$ month (Figure 1) and, over the experiment, the averages were $19.4^{\circ} \mathrm{C}$ and $131 \mathrm{~mm} / \mathrm{month}$, respectively. The number of frosts recorded during May, June, July, August, and September were three, four, six, four, and two, respectively (INMET, 2014).

The treatments evaluated consisted of three forage systems (FS): FS1, pastures of elephant grass cultivated alone, no-legume (NL); FS2, pastures of elephant grass intercropped with arrowleaf clover (AC); and FS3, pastures of elephant grass intercropped with forage peanut (FP). The experiment was arranged in a completely randomized design with three repetitions (paddocks) and repeated measures (grazing cycles).

The experiment was set up in an area of 0.49 ha divided into nine paddocks. The treatments consisted of three forage systems based on elephant grass ('Merckeron Pinda') which was already established in the whole area in rows spaced four meters apart. The previously established stoloniferous forage peanut ('Amarillo') was preserved between rows in three paddocks. In April 2014, scarified and inoculated seeds of arrowleaf clover ('Yuchi') was planted in three paddocks by broadcast seeding at the rate of $10 \mathrm{~kg} / \mathrm{ha}$. In the whole area, ryegrass was broadcasted between rows on scarified soil, at the rate of $30 \mathrm{~kg} / \mathrm{ha}$. In the summer, the development of spontaneous growth species was allowed between rows. The main spontaneous growth species occurring in the experimental area are: Paspalum conjugatum, Paspalum urvillei Steud., Setaria spp., Dichanthelium spp., and Cynodon dactylon.

Base fertilizer was applied, according to the soil analysis, as recommended for the grass-legume intercropping, with $60 \mathrm{~kg} / \mathrm{ha}$ of both $\mathrm{P}_{2} \mathrm{O}_{5}$ and $\mathrm{K}_{2} \mathrm{O}$. Nitrogen fertilization was carried out in the winter, with $30 \mathrm{~kg}$ of N/ha, in the form of urea, in two applications, and in the summer, with $100 \mathrm{~kg}$ of $\mathrm{N} /$ ha in four applications, between November 2013 and February 2014.

Pastures were grazed when ryegrass was near $25 \mathrm{~cm}$ high (use period from May to October) (Aguinaga et al., 2006) and, during the summer, when elephant grass was between 100 and $120 \mathrm{~cm}$ high (Voltolini et al., 2010). The grazing method was rotational stocking, with forage supply (7 kg DM/100 kg body weight) and stocking density (Allen et al., 2011) calculated for one-day occupation period.

Before grazing, the forage mass of the elephant grass in each paddock was estimated by the double sampling technique: five cuts ( $0.5 \mathrm{~m}$ wide by the length of the clump) at $50 \mathrm{~cm}$ from the ground and 20 visual estimates. The same was done between rows, with five cuts $(0.5 \times 0.5 \mathrm{~m})$

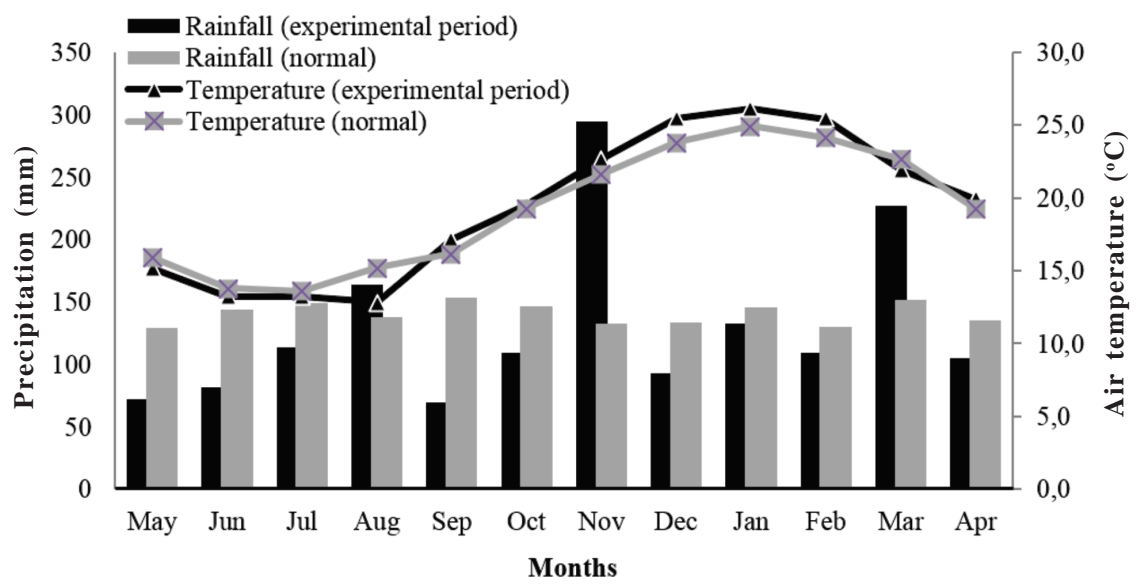

Figure 1. Climate variables, normal and observed over the experimental period, for rain and air temperature. Santa Maria, $2013-2014$. 
close to the ground. The forage cut in the samples was weighed and a subsample was taken to determine the botanical composition of the pasture and morphology of the elephant grass. These components were dried in a forced air oven at $55^{\circ} \mathrm{C}$ to constant weight to determine the contents of partially dried matter and to estimate the participation of each component.

For this study were used Holstein dairy cows with 570 $\mathrm{kg}$ average body weight and $19.5 \mathrm{~kg}$ milk/day average production. The cows received concentrate at a rate of $0.9 \%$ of body weight, formulated with maize, soybean meal, and vitamin-mineral supplement. When not in the experimental areas, the cows were kept in pastures of season, with oat and ryegrass, during winter and spring, and with Tifton 85, Coastcross-1, elephant grass, and spontaneous growth species, both in summer and autumn, receiving the same feed supplementation.

Forage samples were collected separately for the elephant grass and the species between rows, using the grazing simulation technique (Euclides et al., 1992), at the beginning and at the end of each grazing in order to determine the forage nutritional value. The samples were partially dried in a forced air oven at $55^{\circ} \mathrm{C}$, ground in a Willey mill, and packaged as a composite sample, first, by mixing the samples obtained at the entrance and exit of each paddock of the same grazing. Subsequently, the grazing samples were mixed according to the seasons of the year and separated into each stratum of the pasture. The samples were analyzed in laboratory, for crude protein by the Kjeldahl method (AOAC, 1995), neutral detergent fiber (Van Soest et al., 1991), in situ dry matter digestibility, and in situ organic matter digestibility (Mehrez \& Ørskov, 1977). The total digestible nutrient content was estimated by multiplying the percentage of organic matter by the in situ organic matter digestibility divided by 100 (Barber et al., 1984).

The grazing efficiency was estimated by the difference between the forage masses before and after the grazing and transformed into percentage (Hodgson, 1979). The forage export was obtained by multiplying the pre-grazing forage mass by the grazing efficiency, adding up the values obtained for elephant grass and forage between rows. The crude protein export was obtained by multiplying forage exported by crude protein content of each stratum, adding the values obtained for elephant grass and forage between rows. The nitrogen export was calculated by dividing the crude protein export by factor 6.25 . The export of total digestible nutrients was obtained by multiplying forage export by the total digestible nutrient content, adding the values obtained for the elephant grass and forage between rows. The stocking rate was calculated by the ratio of the forage mass difference before and after grazing by the number of days in the grazing cycle and per $450 \mathrm{~kg}$ for the calculation of the animal unit (AU). The DM accumulation rate and pasture production were evaluated in a concomitant experiment in the same area (Seibt et al., 2018).

The statistical analysis was performed using the mean data of grazing conducted in each season of the year. The mean data of the seasons were tested for homogeneity and normality of the errors and then analyzed by lsmeans at the $5 \%$ probability of error using the mixed procedure. The covariance matrix was selected by the lowest AIC (Akaike's Information Criteria) (SAS, 2016). When a significant effect of interaction between forage system and season of the year was found, the means were compared by the Student's $t$ test. In the absence of interaction, the effect of forage system and season of the year was individually tested. Pearson correlation analysis was performed to verify the association among the variables. The mathematical model used was $\mathrm{Y}_{\mathrm{ijk}}=\mathrm{m}+\mathrm{T}_{\mathrm{i}}+\mathrm{R}_{\mathrm{j}}\left(\mathrm{T}_{\mathrm{i}}\right)+\mathrm{E}_{\mathrm{k}}$ $+(\mathrm{TE})_{\mathrm{ik}}+\varepsilon_{\mathrm{ijk}}$, where $\mathrm{Y}_{\mathrm{ijk}}$ is the dependent variable; $\mathrm{m}$ is the mean of all observations; $T_{i}$ is the effect of treatments; $R_{j}$ $\left(\mathrm{T}_{\mathrm{i}}\right)$ is the replication effect within the treatment (error a); $\mathrm{E}_{\mathrm{k}}$ is the effect of the seasons; (TE) ${ }_{\mathrm{ik}}$ is the interaction among treatments and seasons; $\varepsilon_{\mathrm{ijk}}$ is the residual effect (errorb).

\section{RESULTS AND DISCUSSION}

Over the experiment duration, eight grazing cycles were performed in each forage system, two in each season of the year. The average rest period among grazing cycles was $44,41,38$, and 30 days, for winter, spring, summer, and autumn, respectively.

For all studied variables, the P-values of the mixed models are shown in Table 1. For most of the variables evaluated in this study, there was an interaction $(\mathrm{P} \leq 0.05)$ between the forage system and season, especially for those that represent the forage present between lines. This is explained by the diverse composition of the pasture, which includes species from the winter and summer cycle.

There were significant differences among the forage systems (capital letters for in-column comparison) for pregrazing forage mass (Table 2), with the intercropping with forage peanut being superior to the non-legume system and not differing from the intercropping with arrowleaf clover. Differences were also found among seasons (lowercase letters for in-row comparison). In winter, values of forage mass were lower because elephant grass was not present in the pasture composition due to the low temperatures and the frost effect. The average forage mass of the systems with legumes was similar to that found in pastures intercropped with elephant grass and red clover, which was $3.8 \mathrm{t}$ of DM/ha (Azevedo Junior et al., 2012).

There was effect of forage system (capital letters) on the participation of elephant grass, with the intercropping with arrowleaf clover being superior to the non-legume 


\begin{tabular}{|c|c|c|c|c|c|c|c|}
\hline \multirow{2}{*}{$\begin{array}{l}\text { Effect } \\
\text { Pre-grazing } \\
\text { variables }\end{array}$} & \multicolumn{7}{|c|}{ P-value ${ }^{1}$} \\
\hline & Forage mass & Elephant grass & $\begin{array}{l}\text { Senescent material } \\
\text { of elephant grass }\end{array}$ & $\begin{array}{c}\text { Species of } \\
\text { spontaneous growth }\end{array}$ & Ryegrass & Legume & $\begin{array}{r}\text { Dead material } \\
\text { between rows }\end{array}$ \\
\hline Season $(\mathrm{S})$ & $<.0001$ & $<.0001$ & 0.2871 & $<.0001$ & 0.6097 & 0.0012 & $<.0001$ \\
\hline Forage system (FS) & 0.0497 & 0.0495 & 0.0702 & 0.0008 & 0.0372 & 0.0036 & 0.0004 \\
\hline Interaction S x FS & 0.1747 & 0.1267 & 0.2242 & 0.0003 & 0.8309 & 0.0020 & $<.0001$ \\
\hline $\begin{array}{l}\text { Post-grazing } \\
\text { variables }\end{array}$ & Forage mass & Elephant grass & $\begin{array}{l}\text { Senescent material } \\
\text { of elephant grass }\end{array}$ & $\begin{array}{c}\text { Species of } \\
\text { spontaneous growth }\end{array}$ & Ryegrass & Legume & $\begin{array}{l}\text { Dead material } \\
\text { between rows }\end{array}$ \\
\hline Season $(\mathrm{S})$ & $<.0001$ & $<.0001$ & $<.0001$ & $<.0001$ & 0.0607 & 0.0003 & $<.0001$ \\
\hline Forage system (FS) & 0.4450 & 0.0718 & 0.0344 & 0.0005 & 0.2181 & 0.0008 & 0.0277 \\
\hline Interaction S x FS & 0.0332 & 0.0857 & 0.1518 & 0.0314 & 0.1447 & 0.0010 & 0.0413 \\
\hline \multicolumn{3}{|c|}{ Variables of the nutritional value of the forage elephant grass } & $\mathrm{NDF}^{2}$ & $\mathbf{C P}^{3}$ & Digestibility $^{4}$ & TDN $^{5}$ & \\
\hline \multicolumn{3}{|l|}{ Season $(S)$} & 0.0002 & 0.0185 & 0.0034 & 0.6834 & \\
\hline \multicolumn{3}{|l|}{ Forage system (FS) } & 0.2329 & 0.0272 & 0.8354 & 0.4805 & \\
\hline \multicolumn{3}{|l|}{ Interaction S x FS } & 0.7601 & 0.4194 & 0.1074 & 0.1296 & \\
\hline \multicolumn{3}{|c|}{ Variables of the nutritional value of the forage between rows } & NDF & $\mathbf{C P}$ & Digestibility & TDN & \\
\hline \multicolumn{3}{|l|}{ Season $(S)$} & $<.0001$ & $<.0001$ & $<.0001$ & $<.0001$ & \\
\hline \multicolumn{3}{|l|}{ Forage system (FS) } & $<.0001$ & $<.0001$ & 0.0018 & 0.0018 & \\
\hline \multicolumn{3}{|l|}{ Interaction S x FS } & 0.0027 & 0.0079 & $<.0001$ & 0.0034 & \\
\hline \multicolumn{2}{|c|}{ Export nutrients variables } & Grazing efficiency & Forage export & Crude protein export & Nitrogen export & TD Nexport & Stocking rate \\
\hline \multicolumn{2}{|l|}{ Season $(\mathrm{S})$} & $<.0001$ & $<.0001$ & $<.0001$ & $<.0001$ & $<.0001$ & $<.0001$ \\
\hline \multicolumn{2}{|l|}{ Forage system (FS) } & 0.2980 & 0.1435 & 0.0310 & 0.0322 & 0.1364 & 0.3268 \\
\hline \multicolumn{2}{|l|}{ Interaction $\mathrm{S} \times \mathrm{FS}$} & 0.1759 & 0.1224 & 0.1309 & 0.1032 & 0.0714 & 0.0405 \\
\hline
\end{tabular}

${ }^{1}$ P-values according Student's $t$ test. ${ }^{2} \mathrm{NDF}=$ Neutral detergent fiber. ${ }^{3} \mathrm{CD}=$ Crude protein. ${ }^{4}$ In situ dry matter digestibility. ${ }^{5} \mathrm{TDN}=$ Total digestible nutrients. 
system and not differing from the intercropping with forage peanut. This result indicates that the presence of the legume contributed to increasing the forage mass of the companion grass (elephant grass). Differences were found among seasons (lower-case letters), with increase in the participation of elephant grass throughout the seasons, peaking in the Autumn. In this period, there is greater biomass production of elephant grass, with higher contribution of the stems (de Souza Garcia et al., 2011). Both the stem and the senescent material are portions of lesser preference by livestock, causing an increase of elephant grass in the forage mass throughout its vegetative cycle. No differences were found for the participation of elephant grass senescent material. However, the low amount of senescent material indicates a proper management, with grazing height close to $1.0 \mathrm{~m}$ and short intervals among grazing, which reduces senescence losses and increases the efficiency of use of the produced forage. (Simioni et al., 2014).

In relation to the participation of spontaneous growth species, the differences found (capital letters) indicate a greater presence of these species in the non-legume system. This result shows that the presence of legumes in the intercropping systems contributes to decrease the participation of the spontaneous growth species in the pasture composition (Seibt et al., 2018), which was confirmed by correlation analysis $(r=-0.40, \mathrm{P}=0.0006)$. There was no interaction or effect of forage system for the participation of ryegrass.

Regarding the participation of legumes, forage peanut was present in the grazing systems over all seasons of the year, with strong presence in the winter, although being a summer cycle species. Arrowleaf clover was present in three seasons, with contribution like that of the forage peanut in the spring. The average participation of these legumes in the pasture composition are close to those recommended as suitable for the sustainability of the forage system, between 12 and 23\% (Cadisch et al., 1994).

The lowest (capital letters) amount of dead forage material between the rows was observed in the intercropping with forage peanut, indicating that this legume contributes to a higher proportion of green forage. Among the seasons (lower-case letters), the largest values were found in the winter, decreasing over the seasons. These results are due to the participation of species of spontaneous growth, which are mostly summer cycle species and were damaged by low temperatures and frosts.

For post-grazing forage mass (Table 3), there was interaction (capital letters) between forage system and season for forage mass and the fractions species of spontaneous growth and dead forage material between rows.

Significant differences were found among the forage systems (capital letters) for post-grazing forage mass only in the summer. This is possibly caused by the lower intake of forage peanut in relation to the arrowleaf clover. The ingestive behavior of the cows in the forage peanut intercrop may be important for a better sustainability of the forage system, since much of the forage produced remains in the system and its degradation contributes to soil fertility (Vendramini et al., 2014). There was seasonal effect (lower-case letters), with the highest value observed in spring and the lowest in winter.

No differences were found among forage systems for elephant grass participation in the composition of the pasture. It is worth noting that the values are lower than the pre-grazing forage mass (Table 2), which is attributed to the high preference of the cows for elephant grass when compared to the other summer cycle species present in the systems. Among the seasons of the year (lower-case letters), there was increase in the participation of elephant grass, which is related with the values observed in pregrazing forage mass. The senescent material of elephant grass in the post-grazing forage mass remained low, which shows the efficiency of the cultivation in rows, reducing trampling losses (Meinerz et al., 2008).

The participation of species of spontaneous growth in the pasture composition in the post-grazing period was higher than that in the pre-grazing period (Table 2), indicating that they were less eaten by the cows. This is because they are less palatable and are associated with grasses more consumed by cows, such as elephant grass in summer and ryegrass in winter.

The participation of forage peanut in the post-grazing forage mass is high in all seasons, even in winter. This is explained by the milder conditions in this season and the clumps of elephant grass, which with their higher canopy protect the smaller plants, reducing the effect of cold and frost.

The fraction of dead forage material between rows had an increase (lower-case letters), as expected, in all seasons, in relation to the initial forage mass, because of the low intake and the trampling losses.

There was no interaction between forage system and season of the year for nutritional value of elephant grass (Table 4). The neutral detergent fiber of elephant grass had a season effect (lower-case letters), with higher mean in the summer caused by the higher grass growth, implying a greater stem participation, with consequent increase of structural compounds such as cellulose, hemicellulose, and lignin, that compose the fiber fraction in neutral detergent (Macedo Júnior et al., 2007). The means are similar to those found for elephant grass cultivated with other species and under grazing (Azevedo Junior et al., 2012).

Differences in crude protein of elephant grass were found among the forage systems (capital letters), with the intercrop with forage peanut being superior to the other 


\begin{tabular}{|c|c|c|c|c|c|}
\hline \multirow{2}{*}{ FS } & \multicolumn{4}{|c|}{ Season* } & \multirow{2}{*}{ Mean (CI) } \\
\hline & Winter & Spring & Summer & Autumn & \\
\hline \multicolumn{6}{|c|}{ Forage mass (kg of DM/ha) } \\
\hline $\mathrm{NL}^{1}$ & $\mathrm{~ns}$ & $\mathrm{~ns}$ & $\mathrm{~ns}$ & $\mathrm{~ns}$ & $3465^{\mathrm{B}}(3189-3742)$ \\
\hline $\mathrm{AC}^{2}$ & ns & $\mathrm{ns}$ & $\mathrm{ns}$ & ns & $3803^{\mathrm{AB}}(3526-4080)$ \\
\hline $\mathrm{FP}^{3}$ & ns & ns & ns & $\mathrm{ns}$ & $3912^{\mathrm{A}}(3635-4189)$ \\
\hline Mean $(\mathrm{CI})$ & $1853^{\mathrm{b}}(1605-2102)$ & $4383^{\mathrm{a}}(4134-4632)$ & $4444^{\mathrm{a}}(4196-4693)$ & $4226^{\mathrm{a}}(3978-4475)$ & \\
\hline \multicolumn{6}{|c|}{ Forage present in the row } \\
\hline \multicolumn{6}{|c|}{ Elephant grass (\%) } \\
\hline NL & - & $\mathrm{ns}$ & $\mathrm{ns}$ & $\mathrm{ns}$ & $28.9^{\mathrm{B}}(22.2-35.5)$ \\
\hline $\mathrm{AC}$ & - & $\mathrm{ns}$ & $\mathrm{ns}$ & ns & $40.5^{\mathrm{A}}(33.9-47.2)$ \\
\hline FP & - & ns & $\mathrm{ns}$ & $\mathrm{ns}$ & $31.7^{\mathrm{AB}}(25.0-38.3)$ \\
\hline Mean $(\mathrm{CI})$ & - & $18.0^{c}(13.9-22.1)$ & $37.9^{\mathrm{b}}(33.8-42.1)$ & $45.1^{\mathrm{a}}(41.0-49.2)$ & \\
\hline \multicolumn{6}{|c|}{ Forage present between rows } \\
\hline \multicolumn{6}{|c|}{ Species of spontaneous growth (\%) } \\
\hline NL & $23.6^{\mathrm{A}}(19.7-27.5)$ & $30.3^{\mathrm{A}}(28.2-32.4)$ & $50.5^{\mathrm{A}}(42.4-58.7)$ & $53.9^{\mathrm{A}}(44.2-63.7)$ & $\mathrm{ns}$ \\
\hline $\mathrm{AC}$ & $17.5^{\mathrm{B}}(13.6-21.4)$ & $15.7^{\mathrm{B}}(13.6-17.8)$ & $38.2^{\mathrm{B}}(30.1-46.3)$ & $38.5^{\mathrm{B}}(28.7-48.2)$ & $\mathrm{ns}$ \\
\hline FP & $24.9^{\mathrm{A}}(21.0-28.8)$ & $14.0^{\mathrm{B}}(11.9-16.1)$ & $28.3^{\mathrm{B}}(20.2(36.5)$ & $23.1^{\mathrm{C}}(13.3-32.8)$ & $\mathrm{ns}$ \\
\hline Mean $(\mathrm{CI})$ & $22.0^{\mathrm{b}}(19.7-24.2)$ & $20.0^{\mathrm{b}}(18.8-21.2)$ & $39.0^{\mathrm{a}}(34.3-43.7)$ & $38.5^{\mathrm{a}}(32.9-44.1)$ & \\
\hline \multicolumn{6}{|c|}{ Ryegrass (\%) } \\
\hline NL & ns & ns & $\mathrm{ns}$ & $\mathrm{ns}$ & $33.9^{\mathrm{A}}(28.3-32.7)$ \\
\hline $\mathrm{AC}$ & ns & ns & $\mathrm{ns}$ & ns & $24.4^{\mathrm{B}}(18.8-30.0)$ \\
\hline FP & ns & ns & $\mathrm{ns}$ & $\mathrm{ns}$ & $24.0^{\mathrm{B}}(18.5-29.6)$ \\
\hline \multicolumn{6}{|c|}{ Legume (\%) } \\
\hline $\mathrm{AC}$ & $3.3^{\mathrm{B}}(-3.6-10.2)$ & $21.0^{\mathrm{A}}(15.0-27.0)$ & $12.4^{\mathrm{B}}(4.6-20.2)$ & $0.0^{\mathrm{B}}(-2.1-2.2)$ & $\mathrm{ns}$ \\
\hline FP & $26.7^{\mathrm{A}}(19.8-33.6)$ & $28.6^{\mathrm{A}}(22.6-34.7)$ & $29.0^{\mathrm{A}}(21.3-36.8)$ & $29.4^{\mathrm{A}}(27.3-31.5)$ & $\mathrm{ns}$ \\
\hline Mean $(\mathrm{CI})$ & $15.0^{\mathrm{b}}(10.1-19.9)$ & $24.8^{\mathrm{a}}(20.6-29.1)$ & $20.7^{\mathrm{a}}(15.2-26.2)$ & & \\
\hline \multicolumn{6}{|c|}{ Dead material between rows (\%) } \\
\hline NL & ns & $\mathrm{ns}$ & $\mathrm{ns}$ & $\mathrm{ns}$ & $21.1^{\mathrm{A}}(19.3-22.8)$ \\
\hline $\mathrm{AC}$ & ns & $\mathrm{ns}$ & $\mathrm{ns}$ & $\mathrm{ns}$ & $20.8^{\mathrm{A}}(19.0-22.6)$ \\
\hline FP & ns & $\mathrm{ns}$ & $\mathrm{ns}$ & ns & $13.2^{\mathrm{B}}(11.6-15.0)$ \\
\hline Mean $(\mathrm{CI})$ & $39.9^{\mathrm{a}}(37.8-42.0)$ & $18.3^{b}(15.6-21.0)$ & $10.9^{\mathrm{c}}(10.1-11.7)$ & $4.3^{\mathrm{d}}(4.0-4.7)$ & \\
\hline
\end{tabular}

$(\mathrm{P} \leq 0.05)$ according Student's $t$ test. $\mathrm{ns}=$ not significant. $\mathrm{CI}=95 \%$ confidence interval. *Two grazing cycles per season. 
Table 3: Post-grazing forage mass and botanical composition of pasture in different forage systems (FS). Santa Maria, 2013-2014

\begin{tabular}{|c|c|c|c|c|c|}
\hline \multirow{2}{*}{ FS } & \multicolumn{4}{|c|}{ Season* } & \multirow{2}{*}{ Mean (CI) } \\
\hline & Winter & Spring & Summer & Autumn & \\
\hline \multicolumn{6}{|c|}{ Forage mass (kg of DM/ha) } \\
\hline $\mathrm{NL}^{1}$ & $1350^{\mathrm{A}}(1181-1519)$ & $2971^{\mathrm{A}}(2471-3471)$ & $2384^{\mathrm{B}}(2135-2633)$ & $2458^{\mathrm{A}}(2261-2656)$ & $\mathrm{ns}$ \\
\hline $\mathrm{AC}^{2}$ & $1312^{\mathrm{A}}(1143-1481)$ & $2838^{\mathrm{A}}(2338-3339)$ & $2331^{\mathrm{B}}(2083-2580)$ & $2472^{\mathrm{A}}(2274-2670)$ & $\mathrm{ns}$ \\
\hline $\mathrm{FP}^{3}$ & $1156^{\mathrm{A}}(987-1325)$ & $3056^{\mathrm{A}}(2556-3557)$ & $2901^{\mathrm{A}}(2652-3150)$ & $2400^{\mathrm{A}}(2202-2597)$ & $\mathrm{ns}$ \\
\hline Mean $(\mathrm{CI})$ & $1273^{\mathrm{c}}(1175-1370)$ & $2955^{a}(2667-3244)$ & $2539^{\mathrm{b}}(2395-2682)$ & $2443^{\mathrm{b}}(2329-2557)$ & \\
\hline \multicolumn{6}{|c|}{ Forage present in the rowElephant grass (\%) } \\
\hline Mean & - & $2.5^{\mathrm{b}}(2.2-2.9)$ & $19.8^{\mathrm{ab}}(16.1-23.5)$ & $26.7^{\mathrm{a}}(20.3-33.1)$ & \\
\hline \multicolumn{6}{|c|}{ Senescent material of elephant grass $(\%)$} \\
\hline NL & - & ns & ns & ns & $1.1^{\mathrm{B}}(0.5-1.6)$ \\
\hline $\mathrm{AC}$ & - & ns & $\mathrm{ns}$ & $\mathrm{ns}$ & $2.6^{\mathrm{A}}(1.9-3.2)$ \\
\hline FP & - & $\mathrm{ns}$ & $\mathrm{ns}$ & $\mathrm{ns}$ & $1.5^{\mathrm{AB}}(0.8-2.1)$ \\
\hline Mean (CI) & & $0.5^{\mathrm{c}}(-0.1-1.1)$ & $1.5^{\mathrm{b}}(0.9-2.1)$ & $3.2^{\mathrm{a}}(2.6-3.7)$ & \\
\hline
\end{tabular}

Forage present between rowsSpecies of spontaneous growth $(\%)$

\begin{tabular}{|c|c|c|c|c|c|}
\hline NL & $29.6^{\mathrm{A}}(22.2-37.1)$ & $36.8^{\mathrm{A}}(29.4-44.3)$ & $67.4^{\mathrm{A}}(60.0-74.9)$ & $67.5^{\mathrm{A}}(60.0-74.9)$ & ns \\
\hline $\mathrm{AC}$ & $24.1^{\mathrm{A}}(16.6-31.5)$ & $30.4^{\mathrm{AB}}(23.0-37.8)$ & $51.5^{\mathrm{B}}(44.1-59.0)$ & $48.4^{\mathrm{B}}(41.0-55.9)$ & ns \\
\hline FP & $20.2^{\mathrm{A}}(12.8-27.6)$ & $24.3^{\mathrm{B}}(16.9-31.7)$ & $33.2^{\mathrm{C}}(25.8-40.7)$ & $39.8^{\mathrm{C}}(32.3-47.2)$ & ns \\
\hline Mean $(\mathrm{CI})$ & $24.6^{\mathrm{b}}(20.4-28.9)$ & $30.5^{\mathrm{b}}(26.2-34.9)$ & $50.7^{\mathrm{a}}(46.5-55.0)$ & $51.9^{\mathrm{a}}(47.1-56.2)$ & \\
\hline
\end{tabular}

\begin{tabular}{|c|c|c|c|c|c|}
\hline \multicolumn{6}{|c|}{ Legume (\%) } \\
\hline $\mathrm{AC}$ & $\mathrm{ns}$ & $\mathrm{ns}$ & $\mathrm{ns}$ & ns & $9.0^{\mathrm{B}}(1.8-11.6)$ \\
\hline FP & $\mathrm{ns}$ & $\mathrm{ns}$ & $\mathrm{ns}$ & $\mathrm{ns}$ & $29.8^{\mathrm{A}}(24.9-34.7)$ \\
\hline Mean $(\mathrm{CI})$ & $19.2^{\mathrm{a}}(14.0-24.4)$ & $22.7^{\mathrm{a}}(18.5-26.9)$ & $20.8^{\mathrm{a}}(17.4-24.3)$ & $10.3^{\mathrm{b}}(8.4-12.2)$ & \\
\hline \multicolumn{6}{|c|}{ Dead material between rows (\%) } \\
\hline NL & $50.9^{\mathrm{A}}(38.4-63.4)$ & $35.4^{\mathrm{A}}(27.7-43.2)$ & $16.4^{\mathrm{A}}(9.8-22.9)$ & $9.7^{\mathrm{A}}(6.1-13.3)$ & ns \\
\hline $\mathrm{AC}$ & $54.1^{\mathrm{A}}(41.5-66.6)$ & $30.6^{\mathrm{AB}}(22.9-38.3)$ & $15.0^{\mathrm{A}}(8.5-21.6)$ & $13.0^{\mathrm{A}}(9.4-16.7)$ & ns \\
\hline FP & $27.6^{\mathrm{B}}(15.1-40.2)$ & $22.4^{\mathrm{B}}(14.7-30.1)$ & $15.4^{\mathrm{A}}(8.9-22.0)$ & $11.4^{\mathrm{A}}(7.8-15.0)$ & ns \\
\hline Mean $(\mathrm{CI})$ & $44.2^{\mathrm{a}}(37.0-51.4)$ & $29.5^{\mathrm{b}}(25.0-33.9)$ & $15.6^{c}(11.8-19.4)$ & $11.4^{\mathrm{c}}(9.3-13.5)$ & \\
\hline
\end{tabular}


systems. This result demonstrates that the legume contributed to raise the protein content of the companion grass. The means found in each forage system are higher than that reported for the same species of $14.7 \%$ (Azevedo Junior et al., 2012), and between 14 and 15\%, in a study conducted with elephant grass ('Napier'), under irrigation and different levels of nitrogen fertilization (dos Santos Lopes et al., 2005).

No differences for the in situ dry matter digestibility of elephant grass were found among the forage systems, but there were differences among the means per season (lowercase letters), lower in summer and autumn, because the higher growth of elephant grass. For total digestible nutrients, there was no difference neither among systems nor among seasons of the year. The mean values, $79.5 \%$ for in situ digestibility of dry matter and $70.8 \%$ for total digestible nutrients, are higher than those found for elephant grass grown as a monocrop in the same region, $68.8 \%$ and $60.1 \%$, respectively (Meinerz et al., 2008). When comparing the different variables of nutritional value for elephant grass, we also found higher values. This is in part attributed to the grazing management by rotational stocking with occupation of one day and 35 days of rest. For warm-season species such as elephant grass, 30-day grazing cycles are associated with better forage quality when compared to a longer period of 45 days (Deresz, 2001).

There was interaction between forage system and season (capital letters) for the variables of nutritional value of the species present between rows of elephant grass (Table 5), which results from the diversity of plants of different production cycles like ryegrass, legumes, and species of spontaneous growth.

Values of neutral detergent fiber of the forage between rows, in winter, were lower than in the other seasons (lowercase letters). The mean value found of $51.3 \%$ is considered low and is due to the predominance of ryegrass in this season, which is similar to the result observed in a study with pasture of similar botanical composition conducted in the same region (Meinerz et al., 2008). Considering the forage systems (capital letters), in the spring, the lowest neutral detergent fiber values were observed in the legume intercropping. In the other seasons, the lowest values of neutral detergent fiber were associated with the legume participation in the pasture composition $(\mathrm{r}=-0.40 ; \mathrm{P}=$ 0.0006). In general, the neutral detergent fiber of legumes is lower than that of grasses (Cabreira Jobim et al., 2011).

In the non-legume system and in the intercropping with arrowleaf clover (from the summer onwards), the high values (capital letters) of neutral detergent fiber are correlated with the highest participation of spontaneous growth species $(r=0.43 ; P=0.0092)$. In addition, because of the lower preference of the animals, these species enter more rapidly in maturation, decreasing leaf and increasing the stem proportion, with consequent rise in the contents of structural compounds such as cellulose, hemicellulose, and lignin, which make up the neutral detergent fiber fraction (Macedo Júnior et al., 2007).

In relation to crude protein content of the forage between rows, there were differences (capital letters) among the forage systems, which were correlated to the presence of legumes $(\mathrm{r}=0.35, \mathrm{P}=0.0386)$. This finding is confirmed by the crude protein contents found in winter, summer, and autumn. In these seasons, the participation of forage peanut was higher than that of arrowleaf clover, indicating a superiority in crude protein content. In the spring, the participation of legumes was similar (Table 1) as well as the crude protein content of the pasture. Among the seasons (lower-case letters), the highest value verified in winter is associated with the presence of ryegrass. The same did not occur in the spring, when ryegrass is maturing and, consequently, reducing its nutritive value. In summer and

Table 4: Nutritional value of the forage elephant grass in different forage systems (FS). Santa Maria, 2013-2014

\begin{tabular}{|c|c|c|c|c|}
\hline \multirow{2}{*}{ SF } & \multicolumn{3}{|c|}{ Season* } & \multirow{2}{*}{ Mean (CI) } \\
\hline & Spring & Summer & Autumn & \\
\hline \multicolumn{5}{|c|}{ Neutral detergent fiber $(\%)$} \\
\hline Mean (CI) & $58.7^{\mathrm{b}}(57.0-60.4)$ & $65.1^{\mathrm{a}}(63.4-66.8)$ & $60.3^{\mathrm{b}}(58.6-62.0)$ & \\
\hline \multicolumn{5}{|c|}{ Crude protein $(\%)$} \\
\hline NL & $\mathrm{ns}$ & ns & $\mathrm{ns}$ & $16.7^{\mathrm{B}}(16.0-17.4)$ \\
\hline $\mathrm{AC}$ & $\mathrm{ns}$ & ns & $\mathrm{ns}$ & $16.7^{\mathrm{B}}(16.0-17.5)$ \\
\hline FP & $\mathrm{ns}$ & $\mathrm{ns}$ & $\mathrm{ns}$ & $18.1^{\mathrm{A}}(17.4-18.8)$ \\
\hline Mean (CI) & $17.3^{\mathrm{a}}(16.7-18.0)$ & $17.8^{\mathrm{a}}(17.2-18.4)$ & $16.4^{\mathrm{b}}(15.8-17.1)$ & \\
\hline \multicolumn{5}{|c|}{ In situ dry matter digestibility (\%) } \\
\hline Mean (CI) & $80.6^{\mathrm{a}}(79.5-81.8)$ & $78.8^{\mathrm{b}}(77.7-80.0)$ & $78.9^{\mathrm{b}}(77.8-80.1)$ & \\
\hline
\end{tabular}

Rev. Ceres, Viçosa, v. 68, n.5, p. 429-440, sep/oct, 2021 
autumn, the values of crude protein are lower than winter, because of the increase in spontaneous growth species of summer cycle, which usually have lower nutritive value than the species of winter cycle (Barbehenn et al., 2004). Higher and constant contents of crude protein were found in the intercropping with forage peanut due to its greater participation in the different seasons of the year. The mean crude protein content in the intercropping with forage peanut, of $19.5 \%$, is close to that observed in pure pasture of this legume, of $21.12 \%$ (Tambara et al., 2017).

The in situ dry matter digestibility and the total digestible nutrient content of the forage between rows showed differences among forage systems (capital letters) and among seasons (lower-case letters), which was like the behavior observed for crude protein. Among the seasons, there was decrease in the in situ dry matter digestibility correlated with the increase in neutral detergent fiber $(r=-0.41 ; P=0.0149)$, which was attributed to the predominance of summer cycle species of spontaneous growth $(\mathrm{r}=0.43, \mathrm{P}=0.0092)$.

Considering the variables of nutritional value evaluated in the intercropping with arrowleaf clover, the best results were found in the spring, when the legume had a greater participation in the pasture composition and was superior to the non-legume system. There was lower variation in the chemical composition throughout the year in the intercropping with forage peanut, remaining superior to the non-legume system. This is explained by the greater participation of the legume in the pasture composition in all seasons. The nutritive quality of forage peanut was also studied by evaluating the whole plant in an intercropping with Coastcross, with the mean values of $42.46 \%$ and $79.06 \%$, respectively for neutral detergent fiber and dry matter in situ digestibility of forage peanut (Ribeiro et al., 2012).

For grazing efficiency (Table 6), no differences were found among forage systems, which shows that management and supply of forage were similar among treatments. There were differences among seasons (lower-case letters), with higher values in summer and autumn, which is due to the greater contribution of elephant grass to the forage mass (Table 2), with predominance of leaves. For exportation of forage, it should be noted that the highest (lower-case letters) values were obtained in summer and autumn.

There were differences of crude protein export among forage systems (capital letters). The means of the intercropping with legumes were greater than those of the non-legume system. The evaluation of the total annual value showed that the system intercropped with forage

Table 5: Nutritional value of the forage between rows in different forage systems (FS). Santa Maria, 2013-2014

\begin{tabular}{|c|c|c|c|c|}
\hline \multirow{2}{*}{ SF } & \multicolumn{4}{|c|}{ Season* } \\
\hline & Winter & Spring & Summer & Autumn \\
\hline \multicolumn{5}{|c|}{ Neutral detergent fiber $(\%)$} \\
\hline $\mathrm{NL}^{1}$ & $49.5^{\mathrm{AB}}(45.0-54.0)$ & $64.6^{\mathrm{A}}(61.2-68.1)$ & $64.6^{\mathrm{A}}(61.7-67.5)$ & $62.4^{\mathrm{A}}(59.1-65.7)$ \\
\hline $\mathrm{AC}^{2}$ & $55.4^{\mathrm{A}}(50.9-59.9)$ & $56.4^{\mathrm{B}}(53.0-59.9)$ & $65.1^{\mathrm{A}}(62.2-68.0)$ & $64.2^{\mathrm{A}}(60.9-67.5)$ \\
\hline $\mathrm{FP}^{3}$ & $49.0^{\mathrm{B}}(44.5-53.4)$ & $57.0^{\mathrm{B}}(53.6-60.5)$ & $54.8^{\mathrm{B}}(51.9-57.7)$ & $48.9^{\mathrm{B}}(45.6-52.2)$ \\
\hline Mean $(\mathrm{CI})$ & $51.3^{\mathrm{b}}(48.7-53.7)$ & $59.4^{\mathrm{a}}(57.4-61.4)$ & $61.5^{\mathrm{a}}(59.8-63.2)$ & $58.5^{\mathrm{a}}(56.6-60.4)$ \\
\hline \multicolumn{5}{|c|}{ Crude protein $(\%)$} \\
\hline NL & $19.6^{\mathrm{B}}(18.4-20.9)$ & $11.2^{\mathrm{B}}(10.0-12.5)$ & $12.0^{\mathrm{C}}(10.7-13.3)$ & $12.0^{\mathrm{B}}(10.7-13.2)$ \\
\hline $\mathrm{AC}$ & $19.6^{\mathrm{B}}(18.3-20.9)$ & $14.7^{\mathrm{A}}(13.4-15.9)$ & $15.4^{\mathrm{B}}(14.1-16.6)$ & $13.3^{\mathrm{B}}(12.0-14.6)$ \\
\hline FP & $24.2^{\mathrm{A}}(23.0-25.5)$ & $15.5^{\mathrm{A}}(14.3-16.8)$ & $19.8^{\mathrm{A}}(18.5-21.1)$ & $18.3^{\mathrm{A}}(17.0-19.6)$ \\
\hline Mean $(\mathrm{CI})$ & $21.2^{\mathrm{a}}(20.4-21.9)$ & $13.8^{c}(13.1-14.5)$ & $15.7^{\mathrm{b}}(15.0-16.4)$ & $14.5^{\mathrm{c}}(13.8-15.3)$ \\
\hline \multicolumn{5}{|c|}{ In situ dry matter digestibility (\%) } \\
\hline NL & $85.1^{\mathrm{A}}(79.2-90.9)$ & $67.3^{\mathrm{B}}(65.8-68.9)$ & $73.1^{\mathrm{B}}(71.9-74.4)$ & $74.7^{\mathrm{B}}(70.0-79.3)$ \\
\hline $\mathrm{AC}$ & $74.2^{\mathrm{B}}(68.3-80.0)$ & $74.0^{\mathrm{A}}(72.5-75.5)$ & $72.3^{\text {B }}(71.1-73.6)$ & $70.8^{\mathrm{B}}(66.1-75.4)$ \\
\hline FP & $88.0^{\mathrm{A}}(82.2-93.9)$ & $72.8^{\mathrm{A}}(71.3-74.3)$ & $80.5^{\mathrm{A}}(79.3-81.8)$ & $83.1^{\mathrm{A}}(78.4-87.8)$ \\
\hline Mean $(\mathrm{CI})$ & $82.4^{\mathrm{a}}(79.0-85.8)$ & $71.4^{\mathrm{c}}(70.5-72.2)$ & $75.3^{\mathrm{b}}(74.6-76.1)$ & $76.2^{\mathrm{b}}(73.5-78.9)$ \\
\hline \multicolumn{5}{|c|}{ Total digestible nutrients (\%) } \\
\hline NL & $75.9^{\mathrm{A}}(70.7-81.0)$ & $62.5^{\mathrm{B}}(61.0-63.9)$ & $65.9^{\mathrm{B}}(64.8-67.1)$ & $67.4^{\mathrm{B}}(63.3-71.6)$ \\
\hline $\mathrm{AC}$ & $66.0^{\mathrm{B}}(60.8-71.1)$ & $67.3^{\mathrm{A}}(65.9-68.8)$ & $64.9^{\mathrm{B}}(63.7-66.1)$ & $63.1^{\mathrm{B}}(58.9-67.3)$ \\
\hline FP & $78.4^{\mathrm{A}}(73.2-83.6)$ & $66.2^{\mathrm{A}}(64.7-67.6)$ & $72.1^{\mathrm{A}}(70.9-73.3)$ & $74.8^{\mathrm{A}}(70.6-79.0)$ \\
\hline Mean $(\mathrm{CI})$ & $73.4^{\mathrm{a}}(70.4-76.4)$ & $65.3^{c}(64.5-66.2)$ & $67.7^{\mathrm{b}}(67.0-68.4)$ & $68.5^{\mathrm{b}}(66.0-70.9)$ \\
\hline
\end{tabular}

${ }^{1} \mathrm{NL}=$ elephant grass, without legume; ${ }^{2} \mathrm{AC}=$ elephant grass + arrowleaf clover; ${ }^{3} \mathrm{FP}=$ elephant grass + forage peanut. Means followed by capital letters in the columns and lowercase letters in the lines differ $(\mathrm{P} \leq 0.05)$ according Student's $t$ test. $\mathrm{CI}=95 \%$ confidence interval. *Two grazing cycles per season. 
궁 Table 6: Export of nutrients in different forage systems (FS). Santa Maria, 2013-2014

\begin{tabular}{|c|c|c|c|c|c|c|}
\hline \multirow{2}{*}{ SF } & \multicolumn{4}{|c|}{ Season* } & \multirow{2}{*}{ Mean (CI) } & \multirow{2}{*}{ Total (CI) } \\
\hline & Winter & Spring & Summer & Autumn & & \\
\hline \multicolumn{7}{|c|}{ Grazing efficiency (\%) } \\
\hline Mean (CI) & $30.1^{\mathrm{b}}(25.6-34.4)$ & $33.0^{\mathrm{b}}(28.6-37.5)$ & $41.8^{\mathrm{a}}(37.4-46.3)$ & $41.0^{\mathrm{a}}(36.6-45.5)$ & ns & ns \\
\hline \multicolumn{7}{|c|}{ Forage export (kg of DM/ha) } \\
\hline Mean (CI) & $1162^{\mathrm{c}}(705-1618)$ & $2856^{\mathrm{b}}(2399-3312)$ & $3811^{\mathrm{a}}(3355-4268)$ & $3566^{\mathrm{a}}(3109-4022)$ & ns & ns \\
\hline \multicolumn{7}{|c|}{ Crude protein export $(\mathrm{kg} / \mathrm{ha})$} \\
\hline $\mathrm{NL}^{1}$ & ns & ns & ns & ns & $360^{\mathrm{B}}(258-462)$ & $1440^{\mathrm{B}}(992-1888)$ \\
\hline $\mathrm{AC}^{2}$ & ns & ns & $\mathrm{ns}$ & $\mathrm{ns}$ & $515^{\mathrm{A}}(413-616)$ & $2060^{\mathrm{AB}}(1611-2508)$ \\
\hline $\mathrm{FP}^{3}$ & ns & ns & ns & ns & $563^{\mathrm{A}}(462-665)$ & $2253^{\mathrm{A}}(1805-2701)$ \\
\hline Mean $(\mathrm{CI})$ & $243^{c}(170-316)$ & $447^{\mathrm{b}}(374-520)$ & $648^{\mathrm{a}}(575-722)$ & $580^{\mathrm{a}}(506-653)$ & & \\
\hline \multicolumn{7}{|c|}{ Nitrogen export (kg/ha) } \\
\hline NL & $\mathrm{ns}$ & ns & ns & ns & $57.6^{\mathrm{B}}(41.2-74.0)$ & $230^{\mathrm{B}}(158-302)$ \\
\hline $\mathrm{AC}$ & $\mathrm{ns}$ & ns & $\mathrm{ns}$ & ns & $82.4^{\mathrm{A}}(66.0-98.8)$ & $330^{\mathrm{AB}}(258-402)$ \\
\hline FP & ns & ns & ns & ns & $90.1^{\mathrm{A}}(73.7-106.5)$ & $360^{\mathrm{A}}(288-432)$ \\
\hline Mean $(\mathrm{CI})$ & $38.9^{\mathrm{c}}(27.5-50.2)$ & $71.5^{\mathrm{b}}(63.4-79.6)$ & $103.7^{\mathrm{a}}(87.9-119.6)$ & $92.7^{\mathrm{a}}(83.8-101.7)$ & ns & ns \\
\hline Mean $(\mathrm{CI})$ & $850^{c}(536-1164)$ & $1954^{\mathrm{b}}(1640-2268)$ & $2654^{\mathrm{a}}(2340-2968)$ & $2515^{\mathrm{a}}(2201-2829)$ & ns & ns \\
\hline \multicolumn{7}{|c|}{ Stocking rate (cows**/ha/day) } \\
\hline NL & $1.4^{\mathrm{A}}(1.0-1.7)$ & $2.2^{\mathrm{B}}(1.9-2.6)$ & $2.5^{\mathrm{B}}(2.2-2.8)$ & $3.0^{\mathrm{B}}(2.7-3.3)$ & $\mathrm{ns}$ & $\mathrm{ns}$ \\
\hline $\mathrm{AC}$ & $1.5^{\mathrm{A}}(1.1-1.8)$ & $2.2^{\mathrm{B}}(1.9-2.5)$ & $3.2^{\mathrm{A}}(2.9-3.5)$ & $3.9^{\mathrm{A}}(3.5-4.2)$ & ns & ns \\
\hline FP & $1.2^{\mathrm{A}}(0.8-1.5)$ & $2.8^{\mathrm{A}}(2.5-3.1)$ & $2.7^{\mathrm{B}}(2.3-3.0)$ & $3.5^{\mathrm{A}}(3.2-3.9)$ & ns & ns \\
\hline Mean $(\mathrm{CI})$ & $1.3^{\mathrm{c}}(1.1-1.5)$ & $2.4^{\mathrm{b}}(2.2-2.6)$ & $2.8^{\mathrm{ab}}(2.6-3.0)$ & $3.5^{\mathrm{a}}(3.3-3.6)$ & & \\
\hline
\end{tabular}

${ }^{1} \mathrm{NL}=$ elephant grass, without legume; ${ }^{2} \mathrm{AC}=$ elephant grass + arrowleaf clover; ${ }^{3} \mathrm{FP}=$ elephant grass + forage peanut. Means followed by capital letters in the columns and lowercase letters in the lines differ $(\mathrm{P} \leq 0.05)$ according Student's $t$ test. $\mathrm{CV}=$ coefficient of variation. *Two grazing cycles per season. ${ }^{* *}$ Cow average weight of $570 \mathrm{~kg}$. 
peanut was superior to the non-legume system and did not differ from the intercropping with arrowleaf clover. This result was repeated for nitrogen export, which is associated with the crude protein content of the forage.

The total digestible nutrient export showed no differences among the forage systems, possibly due to the varied composition of the forage systems, with participation of winter and summer species. However, differences were found among the seasons (lower-case letters), increasing from winter to spring and from spring to summer, which did not differ from autumn. This effect was also observed for export of both crude protein and nitrogen, a result that is associated with the increase in the export of forage dry matter, with peak production in the summer because of the participation of elephant grass.

The stocking rates were related to the initial forage mass $(r=0.43, P=0.0051)$. In winter, the lowest values are explained by the time interval considered in the calculation: from the sowing of ryegrass and arrowleaf clover in May to the first grazing in August. A gradual increase occurs from spring (lower-case letters), which is expected due to the contribution of the elephant grass to the forage mass. In this season, the intercropping with forage peanut showed superiority over the non-legume system (capital letters). This result is due to the decomposition of part of the plants of this crop in the winter, introducing $\mathrm{N}$ into the system (Vendramini et al., 2014) and contributing to the companion grass in the spring (Table 3 ). The intercropping with arrowleaf clover showed a similar behavior, that is, showed superiority over the non-legume system and contributed to the companion grass in the summer (capital letters).

\section{CONCLUSIONS}

The legumes present in the forage systems contributed to increasing the forage mass of the companion grass and controlling the species of spontaneous growth. The intercropping systems with forage peanut and arrowleaf clover had higher nutritional value and increased export of crude protein and nitrogen. The use of forage peanut led to lower variability of the variables of nutritional value over the year. Intercropped systems that include species with different cycles is recommended to the farmers who wants to maintain the nutritional level of the pastures, using the same area throughout the year.

\section{ACKNOWLEDGEMENTS, FINANCIAL SUPPORT AND FULL DISCLOSURE}

To Conselho Nacional de Desenvolvimento Científico e Tecnológico $(\mathrm{CNPq})$ for granting a doctoral scholarship for the first author. There is no conflict of interests in carrying the research and publishing the manuscript.

\section{REFERENCES}

Abdul-Baki AA, Bryan HH, Klassen W \& Codallo M (2002) Propagation and establishment of perennial peanuts for ground covers along roadsides and highway ramps. Florida State Horticultural Society, 115:267-272.

Aguinaga AAQ, Carvalho PCdF, Anghinoni I, Santos DTd, Freitas FKd \& Lopes MT (2006) Produção de novilhos superprecoces em pastagem de aveia e azevém submetida a diferentes alturas de manejo. Revista Brasileira de Zootecnia, 35:1765-1773.

Allen VG, Batello C, Berretta EJ, Hodgson J, Kothmann M, Li X, McIvor J, Milne J, Morris C, Peeters A, Sanderson M, The F \& Grazing Terminology C (2011) An international terminology for grazing lands and grazing animals. Grass and Forage Science, $66: 2-28$.

AOAC (1995) Official methods of analysis. $16^{\text {th }}$. Gaithersburg, AOAC International. 1015p.

Azevedo Junior RLD, Olivo CJ, Meinerz GR, Agnolin CA, Diehl MS, Moro G, Parra CLC, Quatrin MP \& Horst T (2012) Produtividade de sistemas forrageiros consorciados com amendoim forrageiro ou trevo vermelho. Ciência Rural, 42:2043-2050.

Barbehenn RV, Chen Z, Karowe DN \& Spickard A (2004) C3 grasses have higher nutritional quality than $\mathrm{C} 4$ grasses under ambient and elevated atmospheric $\mathrm{CO}^{2}$. Global Change Biology, 10:1565-1575.

Barber W, Adamson A \& Altman J (1984) New methods of forage evaluation. In: Haresign, W \& Cole, DJA. (Eds.) Recent advances in animal nutrition. London, Butterworths. p.161-176.

Barcellos ADO, Ramos AKB, Vilela L, Junior M \& Bueno G (2008) Sustentabilidade da produção animal baseada em pastagens consorciadas e no emprego de leguminosas exclusivas, na forma de banco de proteína, nos trópicos brasileiros. Revista Brasileira de Zootecnia, 37:51-67.

Cabreira Jobim C, Alves Ferreira G, Harry Bumbieris Junior V, Calixto Junior M \& Tadeu dos Santos G (2011) Cinética de degradação ruminal dos fenos de alfafa e Tifton-85 e da silagem de milho. Semina: Ciências Agrárias, 32:747-758.

Cadisch G, Schunke RM \& Giller KE (1994) Nitrogen cycling in a pure grass pasture and a grass-legume mixture on a red latosol in Brazil. Tropical grasslands, 28:43-43.

de Souza Garcia C, Fernandes AM, de Alencar Fontes CA, Vieira RAM, de Faria Sant'Ana N \& Pimentel VA (2011) Desempenho de novilhos mantidos em pastagens de capim-elefante e capim-mombaça. Revista Brasileira de Zootecnia, 40:403-410.

Deresz F (2001) Milk yield of crossbred Holstein x Zebu cows grazing elephant grass pasture rotationally managed supplemented or not with concentrate. Revista Brasileira de Zootecnia, 30:197-204.

dos Santos Lopes R, da Fonseca DM, de Oliveira RA, Andrade AC, do Nascimento Júnior D \& Mascarenhas AG (2005) Efeito da Irrigação e Adubação na Disponibilidade e Composição Bromatológica da Massa Seca de Lâminas Foliares de CapimElefante1. Revista Brasileira de Zootecnia, 34:20-29.

Euclides VPB, Macedo MCM \& Oliveira MPd (1992) Avaliação de diferentes métodos de amostragem para se estimar o valor nutritivo de forragens sob pastejo. Revista da Sociedade Brasileira de Zootecnia, 21:691-702.

Hodgson J (1979) Nomenclature and definitions in grazing studies. Grass and Forage Science, 34:11-17.

INMET (2014) Banco de dados meteorológicos para ensino e pesquisa. Dados mensais. Estação Meteorológica de Santa Maria cód. A803, 2013-2014. Available at: https://bdmep.inmet.gov.br/ . Accessed on: July 3th, 2014.

Rev. Ceres, Viçosa, v. 68, n.5, p. 429-440, sep/oct, 2021 
Kozloski GV, Perottoni J, Ciocca MLS, Rocha JBT, Raiser AG \& Sanchez LMB (2003) Potential nutritional assessment of dwarf elephant grass (Pennisetum purpureum Schum. cv. Mott) by chemical composition, digestion and net portal flux of oxygen in cattle. Animal Feed Science and Technology, 104:29-40.

Kuinchtner A \& Buriol GA (2016) Clima do Estado do Rio Grande do Sul segundo a classificação climática de Köppen e Thornthwaite. Disciplinarum Scientia, 2:171-182.

Lüscher A, Mueller Harvey I, Soussana J-F, Rees R \& Peyraud J-L (2014) Potential of legume based grassland-livestock systems in Europe: a review. Grass and Forage Science, 69:206-228.

Macedo Júnior GdL, Zanine AdM, Borges I \& Pérez JRO (2007) Qualidade da fibra para a dieta de ruminantes. Ciência Animal, 17:7-17.

Mehrez A \& Ørskov E (1977) A study of artificial fibre bag technique for determining the dig estibility of feeds in the rumen. The Journal of Agricultural Science, 88:645-650.

Meinerz GR, Olivo CJ, Ziech MF, Agnolin CA, Dullius AP \& da Silveira Moraes R (2008) Composição nutricional de pastagens de capim-Elefante submetido a duas estratégias de manejo em pastejo. Acta Scientiarum. Animal Sciences, 30:379-385.

Oliveira TSD, Pereira JC, Reis CSD, Queiroz ACD, Cecon PR \& Gomes ST (2011) Composição químico-bromatológica do capim-elefante submetido à adubação química e orgânica. Revista Brasileira de Saúde e Produção Animal, 12:32-42.

Olivo CJ, Agnolin CA, Aguirre PF, Bem CMD, Araújo TLDRD, Diehl MS \& Meinerz GR (2014) Forage mass and stocking rate of elephant grass pastures managed under agroecological and conventional systems. Revista Brasileira de Zootecnia, 43:289295 .

Olivo CJ, Diehl MS, Agnolin CA, Bratz VF, Aguirre PF \& Sauter CP (2017) Forage systems mixed with forage legumes grazed by lactating cows. Acta Scientiarum. Animal Sciences, 39:19-26.
Ribeiro OL, Cecato U, Rodrigues AM, Faveri JC, Santos GTd, Lugão SMB \& Beloni, T (2012) Composição botânica e química da Coastcross consorciada ou não com Arachis pintoi, com e sem nitrogênio. Revista Brasileira de Saúde e Produção Animal, 13:47-61.

SAS Institute Inc. (2016) Base SAS® 3.5 Studio User's Guide. Cary, Statistical Analysis System Institute. 198p.

Seibt DC, Olivo CJ, Alessio V, Silva AR, Quatrin MP \& Anjos ANAd (2018) Forage production in mixed grazing systems of elephant grass with arrowleaf clover or forage peanut. Revista Ceres, 65:174-180.

Simioni TA, Hoffmann A, Gomes FJ, Mousquer CJ, Teixeira UHG, Fernandes GA, Botini LA \& de Paula DC (2014) Senescência, remoção, translocação de nutrientes e valor nutritivo em gramíneas tropicais. PUBVET, 8:1551-1697.

Streck EV, Kämpf N, Dalmolin RSD, Klamt E, Nascimento PD, Schneider P, Giasson E \& Pinto L (2008) Solos do Rio Grande do Sul. $2^{\text {nd }}$ ed. Porto Alegre, EMATER. 222p.

Tambara AAC, Sippert MR, Jauris GC, Flores JLC, Henz ÉL \& Velho JP (2017) Production and chemical composition of grasses and legumes cultivated in pure form, mixed or in consortium. Acta Scientiarum. Animal Sciences, 39:235-241.

Van Soest PV, Robertson J \& Lewis B (1991) Methods for dietary fiber, neutral detergent fiber, and nonstarch polysaccharides in relation to animal nutrition. Journal of dairy science, 74:35833597 .

Vendramini J, Dubeux Jr JC \& Silveira ML (2014) Nutrient cycling in tropical pasture ecosystems. Revista Brasileira de Ciências Agrárias, 9:308-315.

Voltolini TV, Santos FAP, Martinez JC, Clarindo RL, Penati MA \& Imaizumi H (2010) Características produtivas e qualitativas do capim-elefante pastejado em intervalo fixo ou variável de acordo com a interceptação da radiação fotossinteticamente ativa. Revista Brasileira de Zootecnia, 39:1002-1010. 